\title{
Vitamin D: Current Guidelines and Future Outlook
}

\author{
STEFAN PILZ ${ }^{1 *}$, CHRISTIAN TRUMMER $^{1 *}$, MARLENE PANDIS ${ }^{1}$, VERENA SCHWETZ ${ }^{1}$, FELIX ABERER ${ }^{1}$, \\ MARTIN GRÜBLER ${ }^{1,2}$, NICOLAS VERHEYEN ${ }^{3}$, ANDREAS TOMASCHITZ $^{4,5}$ and WINFRIED MÄRZ ${ }^{5-7}$ \\ ${ }^{1}$ Division of Endocrinology and Diabetology, Department of Internal Medicine, ${ }^{3}$ Department of Cardiology, \\ ${ }^{6}$ Clinical Institute of Medical and Chemical Laboratory Diagnostics, Medical University of Graz, Graz, Austria; \\ ${ }^{2}$ Swiss Cardiovascular Center Bern, Department of Cardiology, Bern University Hospital, Bern, Switzerland; \\ ${ }^{4}$ Specialist Clinic of Rehabilitation Bad Gleichenberg, Bad Gleichenberg, Austria; \\ ${ }^{5}$ Medical Clinic V (Nephrology, Hypertensiology, Endocrinology, Diabetology, Rheumatology), \\ Mannheim Medical Faculty, University of Heidelberg, Mannheim, Germany; \\ ${ }^{7}$ Synlab Academy, Synlab Laboratory Services GmbH, Mannheim, Germany
}

\begin{abstract}
Vitamin D is of public health interest because its deficiency is common and is associated with musculoskeletal diseases, as well as extraskeletal diseases, such as cancer, cardiovascular diseases, and infections. Several health authorities have reviewed the existing literature and published nutritional vitamin D guidelines for the general population. There was a wide consensus that serum 25 hydroxyvitamin $D[25(\mathrm{OH}) D]$ concentration should be used to assess vitamin $D$ status and intake, and that musculoskeletal, and not extraskeletal, effects of vitamin D should be the basis for nutritional vitamin $D$ guidelines. Recommended target levels for $25(\mathrm{OH}) \mathrm{D}$ range from 25 to 50 $\mathrm{nmol} / \mathrm{l}$ (10 to $20 \mathrm{ng} / \mathrm{ml}$ ), corresponding to a vitamin D intake of 400 to 800 International Units (10 to $20 \mu \mathrm{g}$ ) per day. It is of concern that significant sections of the general population do not meet these recommended vitamin $D$ levels. This definitely requires action from a public health perspective.
\end{abstract}

Vitamin D is historically known as a substance that can prevent and cure rickets, a disease that is characterized by mineralisation deficits of the bones, i.e. of the growth plates $(1,2)$. In general, vitamin D is considered to be critical for

*These Authors contributed equally to this article.

Correspondence to: Stefan Pilz, Department of Internal Medicine, Division of Endocrinology and Diabetology, Medical University of Graz, Auenbruggerplatz 15, 8036 Graz, Austria. Tel: +43 6509103667, Fax: +43 316673216, e-mail: stefan.pilz@chello.at

Key Words: Vitamin D, guidelines, supplementation, epidemiology, $25(\mathrm{OH}) \mathrm{D}$, review. bone and mineral metabolism and thus for musculoskeletal health $(2,3)$. Moreover, low vitamin D levels have also been associated with several extra-skeletal diseases such as cancer, infections and cardiovascular diseases, suggesting a wide role of vitamin D in human health (2-5). While a low vitamin D level is, thus, clearly an indicator of a poor health status, it is still largely unclear whether and to what extent vitamin $\mathrm{D}$ may be effective for the prevention and treatment of several extraskeletal diseases $(6,7)$. In light of the scientific controversy on potential effects of vitamin D and a high worldwide prevalence of low vitamin D levels, several health authorities have published nutritional vitamin D guidelines within the past few years (8-10).

In this brief narrative review, we aim to provide a focussed overview, critical discussion, and future outlook of nutritional vitamin D guidelines for the general population, thereby excluding guidelines intended for patient populations. After a brief introduction on vitamin D metabolism, we outline some common basic steps in the development of nutritional vitamin $\mathrm{D}$ guidelines. We then summarise the recommendations of existing vitamin D guidelines before critically discussing them. Finally, we provide a future outlook for vitamin $\mathrm{D}$ in public health, with a particular focus on the potential implications of some recently finished and ongoing randomized controlled trials (RCTs) on vitamin D.

\section{Vitamin D Metabolism}

The major source for vitamin $\mathrm{D}$ is endogenous synthesis in the skin, where ultraviolet-B from sunlight induces the conversion of 7-dehydrocholesterol, a liver-derived vitamin D precursor, to vitamin D (11). Nutritional sources of vitamin D such as fatty fish, mushrooms and eggs, usually play only a minor role 
as a source of vitamin D, while the contribution of storage and release of vitamin D and its metabolites from tissue stores, such as the adipose tissue, is still largely unclear. Vitamin D has two main isoforms, i.e. vitamin $\mathrm{D}_{3}$ (cholecalciferol), the endogenous (human) and animal-derived form, and vitamin $\mathrm{D}_{2}$ (ergocalciferol), the plant-derived form. As these two isoforms generally share the same pathways of metabolism and since a discussion on potential differences between these two isoforms is beyond the scope of this review, we refer to vitamin $\mathrm{D}$ throughout without further differentiating between vitamin $\mathrm{D}_{2}$ and $\mathrm{D}_{3}$. The main circulating vitamin $\mathrm{D}$ form, 25-hydroxyvitamin $\mathrm{D}[25(\mathrm{OH}) \mathrm{D}]$, is generated by hydroxylation of vitamin $\mathrm{D}$ in the liver. $25(\mathrm{OH}) \mathrm{D}$ is then further hydroxylated to 1,25-dihydroxyvitamin $\mathrm{D}[1,25(\mathrm{OH}) \mathrm{D}]$, the so-called active vitamin D hormone, in the kidneys. In addition, several extra-renal tissues also actively metabolize vitamin D and are also, for example, able to convert $25(\mathrm{OH}) \mathrm{D}$ to $1,25(\mathrm{OH}) 2 \mathrm{D}$ at local tissue level (11). The biological effects of $1,25(\mathrm{OH}) 2 \mathrm{D}$ are mediated by binding to the almost ubiquitously expressed vitamin $\mathrm{D}$ receptor (VDR), resulting in the regulation of hundreds of genes (11). Thus, 1,25(OH)2D functions like a classic steroid hormone with vitamin D-binding protein (DBP) being the main transport protein for vitamin D metabolites in the circulation. Catabolism of vitamin D metabolites is initiated by 24-hydroxylation to form biologically less active metabolites that are finally excreted via the bile and urine.

\section{Development of Nutritional Vitamin D Guidelines}

Recommendations for dietary vitamin D requirements [called dietary reference intakes (DRI) or dietary reference values (DRV)] are generally based on pre-defined processes such as the risk assessment framework approach that aim to address key questions/topics that are essential to develop nutritional vitamin D guidelines (12-16). A very simplified outline of the usual key steps required to develop nutritional vitamin D guidelines for the general population is given below.

A main assumption underlying virtually all vitamin D guidelines is that 'total' serum $25(\mathrm{OH}) \mathrm{D}$ can be used as a biomarker of vitamin D status in general, and of vitamin D intake under conditions of minimal or no ultraviolet-B (sunlight) exposure. This assumption is made being aware of the relatively high inter-laboratory and inter-assay variability of $25(\mathrm{OH}) \mathrm{D}$ measurements, and in view of the accumulating evidence on the role of DBP and its impact on the 'free' and 'bioavailable' (i.e. free and albumin-bound) 25(OH)D concentrations $(17,18)$. Another assumption is that dietary requirements for other potentially interacting nutrients (such as calcium) are met.

The central question for guideline panels is whether there is sufficient evidence to claim a causal relationship between vitamin D status and certain health outcomes. For this aim, systematic evidence-based reviews (SEBR) are conducted to assess the relationship of vitamin D status and vitamin D interventions with skeletal and extra-skeletal health outcomes. Importantly, different study types, including cross-sectional and prospective observational studies, and not only RCTs or meta-analyses of RCTs, are considered in these SEBR. DRI or DRV for vitamin D are only released if existing evidence is considered sufficient in terms of a cause and effect relationship between vitamin $\mathrm{D}$ and certain health outcomes.

Following the identification of such a cause and effect relationship, the guideline panel aims to characterize a doseresponse curve. Importantly, dose-response relationships between vitamin $\mathrm{D}$ intakes and health outcomes cannot be reliably calculated due to insufficient evidence; therefore serum $25(\mathrm{OH}) \mathrm{D}$, as a biomarker of vitamin $\mathrm{D}$ intake, is usually used. This key process in determining the $25(\mathrm{OH}) \mathrm{D}$ and health outcome relationship results in the formulation of certain 'target' $25(\mathrm{OH}) \mathrm{D}$ concentrations, including the estimated average requirements (EAR), i.e. the $25(\mathrm{OH}) \mathrm{D}$ level at the estimated median requirement, and the recommended dietary allowance (RDA), i.e. the $25(\mathrm{OH}) \mathrm{D}$ level that meets or exceeds the vitamin $\mathrm{D}$ requirements of $97.5 \%$ of the population. If the standard deviation (SD) of the EAR is known, the RDA is set as the EAR plus twice the SD. Alternatively, the RDA can be estimated as 1.2 times the EAR if the data about variability in requirements are insufficient. If the EAR cannot be defined due to insufficient evidence, adequate intakes (AI) are recommended instead of RDAs. Although guideline panels perform extensive reviews of the literature, the final decision for setting the EAR/RDA/AI is usually not based on a specific statistical analysis, but rather on a panel decision taking into account the systematically reviewed whole body of literature.

After setting the 25(OH)D levels for the EAR/RDA/AI, the guideline panel aims to calculate the vitamin $D$ intake required to achieve these desired $25(\mathrm{OH}) \mathrm{D}$ levels. For this aim, meta-regression analysis is performed on the achieved serum $25(\mathrm{OH}) \mathrm{D}$ according to total vitamin $\mathrm{D}$ intake. For this meta-regression analysis, conditions of minimal to no sunshine exposure are assumed so that $e . g$. only vitamin D RCTs performed during winter season at northern latitudes in Europe and Antarctica are used to calculate the doseresponse relationship between vitamin $\mathrm{D}$ intake and serum $25(\mathrm{OH}) \mathrm{D}$. The resulting regression curve on vitamin $\mathrm{D}$ intake and serum $25(\mathrm{OH}) \mathrm{D}$ shows the mean responses and the $95 \%$ confidence intervals (CI) around the mean response. It is critical for data interpretation and understanding that the 95\% CI of this meta-regression analysis does not mean that $95 \%$ of the population will lie within this $95 \% \mathrm{CI}$, but rather that this $95 \%$ CI reflects the uncertainty about the position of the regression line. Some guidelines also calculate socalled $95 \%$ prediction intervals (PI) that allow for an approximation for the estimation of the requirements of $95 \%$ 
of individuals in the overall population (19). Importantly, almost all nutritional vitamin $\mathrm{D}$ guidelines assume conditions of minimal or no sun exposure and acknowledge that the dietary vitamin $\mathrm{D}$ requirements may be lower or even be zero in the presence of dermal vitamin D synthesis.

In addition to EAR/RDA/AI, guideline panels also set the tolerable upper intake level that is the "highest average daily nutrient intake level that is likely to pose no risk of adverse health effects to almost all individuals in the general population. As intake increases above the upper limit, the potential risk of adverse effects may increase" (15).

\section{Overview of Vitamin D Guidelines}

An excellent general overview of nutritional guidelines for vitamin D has been published (10). In general, recommended daily doses for vitamin D have significantly increased over the past 10 years. Many old guidelines recommended a daily vitamin D intake of 400 International Units (IU) (40 IU are equivalent to $1 \mu \mathrm{g}$ ) per day because this approximates to the vitamin D content of one teaspoon of cod-liver oil that was historically observed to be sufficient to prevent rickets $(10,20)$.

Nowadays, the Institute of Medicine (IOM) report on vitamin D and calcium released in 2010 is considered the benchmark for recent vitamin D guidelines for developing DRV/DRI $(21,22)$. The IOM concluded that the evidence on skeletal, but not on non-skeletal health outcomes, was sufficient to provide a sound scientific basis for vitamin D intake requirements. The IOM report selected outcomes such as calcium absorption, bone mineral density, osteomalacia and rickets. Risk of adverse consequences with reference to these outcomes increases below a $25(\mathrm{OH}) \mathrm{D}$ level of of 30 $\mathrm{nmol} / \mathrm{l}$ (divide by 2.496 to convert to $\mathrm{ng} / \mathrm{ml}$ ), whereas there seems to be no additional benefit of a $25(\mathrm{OH}) \mathrm{D}$ level higher than $50 \mathrm{nmol} / 1$. Concentrations of $25(\mathrm{OH}) \mathrm{D}$ of between 30 and $50 \mathrm{nmol} / 1$ are a grey zone in which the median vitamin $D$ requirement may lie. Therefore, the IOM report set the EAR at $400 \mathrm{IU}$ per day, corresponding to a $25(\mathrm{OH}) \mathrm{D}$ level of $40 \mathrm{nmol} / 1$, and recommends an RDA for vitamin D of 600 IU per day for those aged 1-70 years and 800 IU per day for older individuals, corresponding to a $25(\mathrm{OH}) \mathrm{D}$ level of $50 \mathrm{nmol} / \mathrm{l}$. The higher RDA for older individuals was explained by, amongst other reasons, a higher uncertainty of the available evidence for some age-related characteristics such as a higher fracture risk, and by RCT data supporting the efficacy of 800 IU per day for reduction of fracture risk. Due to limited evidence, an AI of $400 \mathrm{IU}$ of vitamin D per day was set for the ages of 0 to 12 months. The upper limit for daily vitamin D intake was set at 1,000 IU for those aged 0 to 6 months, 1,500 IU for 6 to 12 months, 2,500 IU for ages 1 to 3 years, 3,000 IU for ages 4 to 8 years, and 4000 IU for individuals aged 9 years and older.
The European Food Safety Authority (EFSA) released dietary reference values for vitamin D in 2016 and considered, in line with the IOM report, a serum $25(\mathrm{OH}) \mathrm{D}$ level of $50 \mathrm{nmol} / \mathrm{l}$ as a suitable target (23). The AIs for daily vitamin D intakes were set at 600 IU for individuals aged 1 year and older, and at 400 IU for infants aged 7 to 11 months. Evidence was considered insufficient for setting AI in the first half-year of life, but it was noted that $400 \mathrm{IU}$ per day are considered adequate for the majority of infants at this age (19). The upper limits for daily vitamin D intake set by the EFSA are 1000 IU in the first year of life, 2000 IU for 1 to 10 years, and 4000 IU for ages 11 years and older (23).

While we consider the IOM and the EFSA reports as the main nutritional vitamin $\mathrm{D}$ guidelines for the general population, we briefly touch a few aspects of other reports in this area and refer to other publications regarding a detailed list of all available guidelines (10). In 2012, the Nutrition Societies in Germany, Austria and Switzerland (DACH) published new reference values for vitamin $\mathrm{D}$ and considered a serum $25(\mathrm{OH}) \mathrm{D}$ level of $50 \mathrm{nmol} / \mathrm{l}$ or higher as an indicator of optimal vitamin D status (24). To achieve this level, a daily vitamin D intake of 800 IU per day for ages 1 year and older was recommended based on Irish RCTs by Cashman et al., who reported that a daily vitamin D intake of $800 \mathrm{IU}$ per day is sufficient to achieve a $25(\mathrm{OH}) \mathrm{D}$ level of at least $50 \mathrm{nmol} / \mathrm{l}$ in about $90 \%$ to $95 \%$ of the Irish population $(24,25)$. In the first year of life, $400 \mathrm{IU}$ of vitamin D were recommended (24). In the UK, the Scientific Advisory Committee on Nutrition (SACN) concluded that serum concentrations of $25(\mathrm{OH}) \mathrm{D}$ levels should not fall below $25 \mathrm{nmol} / \mathrm{l}$ at any time of the year in order to preserve musculoskeletal health (26). To achieve this, the SACN report recommends a reference nutrient intake, i.e. the amount of vitamin $\mathrm{D}$ that is likely to meet the needs of $97.5 \%$ of the population, of 400 IU of vitamin D per day for individuals aged 4 years or older. Data were considered insufficient for younger children but a "safe intake" of 340 to $400 \mathrm{IU}$ per day has been recommended for ages 0 to $<1$ year, and of $400 \mathrm{IU}$ per day for ages 1 up to $<4$ years. Several other nutritional vitamin $\mathrm{D}$ guidelines have been published, with the vast majority recommending target levels for $25(\mathrm{OH}) \mathrm{D}$ in the range of 25 to $50 \mathrm{nmol} / \mathrm{l}$ corresponding to vitamin $\mathrm{D}$ intakes ranging from 400 to 800 IU per day (10). In this context, we also want to stress that we restrict our review to nutritional vitamin D guidelines for the general population and we do not list or discuss vitamin D guidelines for patient populations, nor certain expert recommendations in this field (27-29).

\section{Comment on Vitamin D Guidelines}

It is beyond the scope of this review to address specific potential limitations of the above-mentioned nutritional vitamin D guidelines, but it should be acknowledged that the IOM report has been the subject of intensive discussion (8, 
30, 31). In particular, the interpretation of a post-mortem bone biopsy study by Priemel et al. on the relationship between $25(\mathrm{OH}) \mathrm{D}$ and signs of osteomalacia has caused much controversy, as published elsewhere $(8,30,31)$. Anyway, we greatly appreciate the guideline panels for their work and simply want to comment on some aspects that are, in our opinion, of relevance with reference to the above mentioned DRI.

The huge gap between recommended DRI for vitamin D and the actual high prevalence of vitamin D deficiency in the general population is of major concern $(9,32,33)$. This definitely requires action from public health authorities to improve the vitamin D status in the general population in order to meet the dietary vitamin D requirements $(34,35)$. In particular vitamin $\mathrm{D}$ fortification of food, but also a combination of different approaches, is required to address the public health problem of vitamin D deficiency $(34,35)$. If health authorities are not seriously willing to address this issue, it may cause a significant public health burden. It should, however, also be stressed that it is important to avoid potential oversupplementation with vitamin $\mathrm{D}$ in the general population, although it seems logical that many individuals will start to take vitamin D supplements on a regular basis as long as health authorities release guidelines but do not initiate actions to meet the dietary vitamin D requirements (36). Interestingly, in the US, the daily vitamin D supplement use of $\geq 1,000$ IU (with 95\% CI) increased from $0.3 \%(0.1-0.5 \%)$ in $1999-2000$, to $18.2 \%(16.0-20.7 \%)$ in 2013-2014 (36).

A limitation of current vitamin D guidelines is that the meta-regression analyses for the dose-response relationship between vitamin $\mathrm{D}$ intake and serum 25(OH)D are based on aggregate data and not on individual participant data (IPD) (37-39). The point is that meta-regression analyses based on aggregate data cut the information down to aggregate data of study groups instead of using the complete individual data, so that only between-study variability but not betweenindividual variability was considered in existing vitamin D guidelines (37-39). To address this issue, Cashman et al. performed a meta-regression analysis from IPD of seven vitamin D RCTs during winter including 882 participants (39). The vitamin $\mathrm{D}$ intake requirement to achieve a $25(\mathrm{OH}) \mathrm{D}$ level of at least $50 \mathrm{nmol} / 1$ in $\geq 97.5 \%$ of the individuals was 560 IU vitamin D per day when the metaregression analysis was based on the conventional aggregate data, whereas it was 1,040 IU of vitamin D per day when calculated by the IPD-based approach (39). Interestingly, a recent RCT on vitamin D performed in 201 women during winter in Germany fits these data well, as a similar vitamin D dose (i.e. 800 IU vitamin D per day plus nutritional vitamin D intake, which is usually between 100 to $200 \mathrm{IU}$ per day) has been shown to fulfil the dietary vitamin D requirement (40). Therefore, IPD meta-analyses should be the preferred statistical approach when carrying out metaanalyses and generating dose-response curves for nutritional guidelines.

\section{Future Outlook}

While several nutritional vitamin D guidelines have been published within the past few years, future tasks include working on and implementing public health strategies (in particular mandatory vitamin D fortification of food) to meet the dietary vitamin D requirements in the general population. Initiatives such as the EU ODIN project (Food-based solutions for Optimal vitamin D Nutrition and health throughout the life cycle; FP7-KBBE-2013-7-single-stage; Grant agreement no: 613977) aim to address this issue and will hopefully make a difference to public health policies in the future (35). These efforts will hopefully lead to a wide introduction of vitamin D food fortification (35).

Knowledge on vitamin D effects is significantly increasing as many RCTs on vitamin D have just been published or will be finished soon (41-46). The large vitamin D RCTs on clinical endpoints published in 2017 have not shown beneficial effects of vitamin D $(43,44)$. These findings come as no surprise as these RCTs have several limitations, such as the inclusion of individuals regardless of their $25(\mathrm{OH}) \mathrm{D}$ status, thus ignoring the results of meta-analyses showing that the risk of adverse health outcomes such as mortality is only significantly increased at very low $25(\mathrm{OH}) \mathrm{D}$ levels $(47,48)$. Considering that the associations of $25(\mathrm{OH}) \mathrm{D}$ and some health outcomes display a U- or J-shaped relationship, the achieved 25(OH)D levels of the placebo and intervention groups of some recent RCTs do not meaningfully differ with regard to relative risks for e.g. mortality when plotting the two groups onto a $25(\mathrm{OH}) \mathrm{D}$ and mortality regression curve $(43,44,47,48)$. Further potential limitations of these vitamin $\mathrm{D}$ trials are low response rates and access to vitamin D supplements and laboratory tests for $25(\mathrm{OH}) \mathrm{D}(49)$. Another problem with these RCTs is that they evaluated relatively high doses of vitamin $\mathrm{D}$ and not the doses required to meet the DRI, that are much lower. This is of concern, in particular when considering that a higher vitamin D dose may even be worse compared to a lower dose, as shown in a RCT with respect to risk of falls (50). Moreover, findings such as those from the EVITA trial showing no beneficial effect of 3 years of vitamin D supplementation on mortality or other clinical endpoints in 400 heart failure patients with low $25(\mathrm{OH}) \mathrm{D}$ levels should be accepted and communicated as relatively clear results of no effect (45). Apart from this, it should be acknowledged that long-term RCTs are required to evaluate health outcomes such as cancer, multiple sclerosis or Alzheimer's disease adequately, but such long-lasting trials would also increase the risk of withdrawal and low adherence (49). Besides RCTs, Mendelian randomization studies that 
evaluate whether genetically determined variation in $25(\mathrm{OH}) \mathrm{D}$ is associated with health outcomes are also needed, as they enable us to study life-long exposure $(49,51,52)$. To conclude this future outlook for vitamin D, we are of the opinion that the accurate interpretation of vitamin $\mathrm{D}$ trials and their translation into potential public health actions and information will be one of the major challenges in the near future, particularly in view of reports of negative, null and positive effects of vitamin D $(45,50,52-58)$.

\section{Conclusion}

Nutritional vitamin D guidelines usually recommend target levels for $25(\mathrm{OH}) \mathrm{D}$ of 25 to $50 \mathrm{nmol} / \mathrm{l}$, corresponding to vitamin D intakes ranging from 400 to 800 IU per day. The alarming fact that significant sections of the general population do not meet these dietary vitamin D recommendations requires action from a public health perspective. Finally, it will be a challenge to accurately interpret the findings of large RCTs on vitamin D and to further improve our knowledge on vitamin D effects, with a particular focus on severely vitamin D-deficient individuals and on Mendelian randomization studies.

\section{Acknowledgements}

Martin Grübler is supported by the EU project (Food-based solutions for Optimal vitamin D Nutrition and health throughout the life cycle; FP7-KBBE-2013-7-single-stage; Grant agreement no: 613977).

\section{References}

1 Uday S and Högler W: Nutritional rickets and osteomalacia in the twenty-first century: Revised concepts, public health, and prevention strategies. Curr Osteoporos Rep 6: 667-675, 2017.

2 Pilz S, Gaksch M, Hartaigh BÓ, Tomaschitz A and März W: Vitamin D in preventive medicine. Anticancer Res 35: 11611170, 2015.

3 Theodoratou E, Tzoulaki I, Zgaga L and Ioannidis JP: Vitamin $\mathrm{D}$ and multiple health outcomes: umbrella review of systematic reviews and meta-analyses of observational studies and randomised trials. BMJ 348: g2035, 2014.

4 Feldman D, Krishnan AV, Swami S, Giovannucci E and Feldman BJ:The role of vitamin $\mathrm{D}$ in reducing cancer risk and progression. Nat Rev Cancer 14: 342-357, 2014.

5 Pilz S, Verheyen N, Grübler MR, Tomaschitz A and März W: Vitamin D and cardiovascular disease prevention. Nat Rev Cardiol 13: 404-417, 2016.

6 Autier P, Boniol M, Pizot C and Mullie P: Vitamin D status and ill health: a systematic review. Lancet Diabetes Endocrinol 2: 76-89, 2014

7 Rejnmark L, Bislev LS, Cashman KD, Eiríksdottir G, Gaksch M, Grübler M, Grimnes G, Gudnason V, Lips P, Pilz S, van Schoor NM, Kiely M and Jorde R: Non-skeletal health effects of vitamin D supplementation: A systematic review on findings from meta-analyses summarizing trial data. PLoS One 12: e0180512, 2017.
8 Holick MF: The vitamin D deficiency pandemic: Approaches for diagnosis, treatment and prevention. Rev Endocr Metab Disord 18: 153-165, 2017.

9 Cashman KD, Dowling KG, Škrabáková Z, Gonzalez-Gross M, Valtueña J, De Henauw S, Moreno L, Damsgaard CT, Michaelsen KF, Mølgaard C, Jorde R, Grimnes G, Moschonis G, Mavrogianni C, Manios Y, Thamm M, Mensink GB, Rabenberg M, Busch MA, Cox L, Meadows S, Goldberg G, Prentice A, Dekker JM, Nijpels G, Pilz S, Swart KM, van Schoor NM, Lips P, Eiriksdottir G, Gudnason V, Cotch MF, Koskinen S, Lamberg-Allardt C, Durazo-Arvizu RA and Sempos CT, Kiely M: Vitamin D deficiency in Europe: pandemic? Am J Clin Nutr 103: 1033-1044, 2016.

10 Bouillon R: Comparative analysis of nutritional guidelines for vitamin D: Nat Rev Endocrinol 13: 466-479, 2017.

11 Christakos S, Dhawan P, Verstuyf A, Verlinden L and Carmeliet G: Vitamin D: metabolism, molecular mechanism of action, and pleiotropic effects. Physiol Rev 96: 365-408, 2016.

12 Cashman KD and Kiely M: EURRECA-Estimating vitamin D requirements for deriving dietary reference values. Crit Rev Food Sci Nutr 53: 1097-1109, 2013.

13 Cashman KD and Kiely M: Recommended dietary intakes for vitamin D: Where do they come from, what do they achieve and how can we meet them? J Hum Nutr Diet 27: 434-442, 2014.

14 Cashman KD: Vitamin D: dietary requirements and food fortification as a means of helping achieve adequate vitamin D status. J Steroid Biochem Mol Biol 148: 19-26, 2015.

15 Institute of Medicine. Dietary Reference Intakes: the essential guide to nutrient requirements. Washington, DC: National Academies Press, 2006.

16 Atkinson SA: Defining the process of Dietary Reference Intakes: framework for the United States and Canada. Am J Clin Nutr 94: 655S-7S, 2011.

17 Binkley N, Dawson-Hughes B, Durazo-Arvizu R, Thamm M, Tian L, Merkel JM, Jones JC, Carter GD and Sempos CT: Vitamin D measurement standardization: The way out of the chaos. J Steroid Biochem Mol Biol 173: 117-121, 2017.

18 Chun RF, Peercy BE, Orwoll ES, Nielson CM, Adams JS and Hewison M: Vitamin D and DBP: the free hormone hypothesis revisited. J Steroid Biochem Mol Biol 144: 132-137, 2014.

19 EFSA NDA Panel (EFSA Panel on Dietetic Products, Nutrition and Allergies), 2016. Scientific opinion on dietary reference values for vitamin D: EFSA Journal 14: 4547, 145 pp., 2016.

20 American Academy of Pediatrics, Committee on Nutrition. The prophylactic requirement and the toxicity of vitamin $D$ : Pediatrics 31: 512-525, 1963.

21 Institute of Medicine. Dietary Reference Intakes for calcium and vitamin D: Washington, DC: National Academies Press, 2010.

22 Ross AC, Manson JE, Abrams SA, Aloia JF, Brannon PM, Clinton SK, Durazo-Arvizu RA, Gallagher JC, Gallo RL, Jones G, Kovacs CS, Mayne ST, Rosen CJ and Shapses SA: The 2011 report on dietary reference intakes for calcium and vitamin D from the Institute of Medicine: what clinicians need to know. J Clin Endocrinol Metab 96: 53-58, 2011.

23 EFSA Panel on Dietetic Products, Nutrition and Allergies (NDA); Scientific Opinion on the Tolerable Upper Intake Level of vitamin D: EFSA J 10: 2813, 2012.

24 German Nutrition Society. New reference values for vitamin D: Ann Nutr Metab 60: 241-246, 2012. 
25 Cashman KD, Hill TR, Lucey AJ, Taylor N, Seamans KM, Muldowney S, Fitzgerald AP, Flynn A, Barnes MS, Horigan G, Bonham MP, Duffy EM, Strain JJ, Wallace JM and Kiely M: Estimation of the dietary requirement for vitamin D in healthy adults. Am J Clin Nutr 88: 1535-1542, 2008.

26 Scientific Advisory Committee on Nutrition Report on Vitamin D and Health. Available online: https://www.gov.uk/government/ uploads/system/uploads/attachment_data/file/537616/SACN_Vit amin_D_and_Health_report.pdf (accessed on 12 July 2017)

27 Holick MF, Binkley NC, Bischoff-Ferrari HA, Gordon CM, Hanley DA, Heaney RP, Murad MH and Weaver CM; Endocrine Society. Evaluation, treatment, and prevention of vitamin D deficiency: an Endocrine Society clinical practice guideline. J Clin Endocrinol Metab 96: 1911-1930, 2011.

28 Kanis JA, McCloskey EV, Johansson H, Cooper C, Rizzoli R, Reginster JY, Scientific Advisory Board of the European Society for Clinical and Economic Aspects of Osteoporosis and Osteoarthritis (ESCEO) and the Committee of Scientific Advisors of the International Osteoporosis Foundation (IOF): European guidance for the diagnosis and management of osteoporosis in postmenopausal women. Osteoporos Int 24: 2357, 2013.

29 Brouwer-Brolsma EM, Bischoff-Ferrari HA, Bouillon R, Feskens EJ, Gallagher CJ, Hypponen E, Llewellyn DJ, Stoecklin E, Dierkes J, Kies AK, Kok FJ, Lamberg-Allardt C, Moser U, Pilz S, Saris WH, van Schoor NM, Weber P, Witkamp R, Zittermann A and de Groot LC: Vitamin D: do we get enough? A discussion between vitamin D experts in order to make a step towards the harmonisation of dietary reference intakes for vitamin D across Europe. Osteoporos Int 24: 15671577, 2013.

30 Priemel M, von Domarus C, Klatte TO, Kessler S, Schlie J, Meier S, Proksch N, Pastor F, Netter C, Streichert T, Püschel K and Amling $\mathrm{M}$ : Bone mineralization defects and vitamin $\mathrm{D}$ deficiency: histomorphometric analysis of iliac crest bone biopsies and circulating 25-hydroxyvitamin D in 675 patients. J Bone Miner Res 25: 305-312, 2010.

31 Rosen CJ, Abrams SA, Aloia JF, Brannon PM, Clinton SK, Durazo-Arvizu RA, Gallagher JC, Gallo RL, Jones G, Kovacs CS, Manson JE, Mayne ST, Ross AC, Shapses SA and Taylor CL: IOM committee members respond to Endocrine Society vitamin D guideline. J Clin Endocrinol Metab 97: 1146-1152, 2012.

32 Wahl DA, Cooper C, Ebeling PR, Eggersdorfer M, Hilger J, Hoffmann K, Josse R, Kanis JA, Mithal A, Pierroz DD, Stenmark J, Stöcklin E and Dawson-Hughes B: A global representation of vitamin D status in healthy populations. Arch Osteoporos 7: 155-172, 2012.

33 Pilz S, Dobnig H, Tomaschitz A, Kienreich K, Meinitzer A, Friedl C, Wagner D, Piswanger-Sölkner C, März W and Fahrleitner-Pammer A: Low 25-hydroxyvitamin D is associated with increased mortality in female nursing home residents. J Clin Endocrinol Metab 97: 653-657, 2012.

34 Kiely M and Black LJ: Dietary strategies to maintain adequacy of circulating 25-hydroxyvitamin D concentrations. Scand J Clin Lab Invest Suppl 243: 14-23, 2012.

35 Kiely M and Cashman KD, on behalf of the ODIN Consortium. The ODIN project: development of food-based approaches for prevention of vitamin D deficiency throughout life. Nutr Bull 40: 235-246, 2015.
36 Rooney MR, Harnack L, Michos ED, Ogilvie RP, Sempos CT and Lutsey PL: trends in use of high-dose vitamin D supplements exceeding 1000 or 4000 international units daily, 1999-2014. JAMA 317: 2448-2450, 2017.

37 Riley RD, Higgins JP and Deeks JJ: Interpretation of random effects meta-analyses. BMJ 342: d549, 2011.

38 Vale CL, Rydzewska LH, Rovers MM, Emberson JR, Gueyffier F and Stewart LA; Cochrane IPD Meta-analysis Methods Group. Uptake of systematic reviews and meta-analyses based on individual participant data in clinical practice guidelines: descriptive study. BMJ 350: h1088, 2015.

39 Cashman KD, Ritz C, Kiely M, Odin Collaborators: Improved dietary guidelines for vitamin $\mathrm{d}$ : application of individual participant data (IPD)-level meta-regression analyses. Nutrients 9: 469, 2017.

40 Pilz S, Hahn A, Schön C, Wilhelm M and Obeid R: effect of two different multimicronutrient supplements on vitamin $\mathrm{D}$ status in women of childbearing age: a randomized trial. Nutrients 9: 30, 2017.

41 Kupferschmidt K: Uncertain verdict as vitamin D goes on trial. Science 337: 1476-1478, 2012.

42 Pilz S, Rutters F and Dekker JM: Disease prevention: vitamin D trials. Science 338: 883, 2012.

43 Lappe J, Watson P, Travers-Gustafson D, Recker R, Garland C, Gorham E, Baggerly K and McDonnell SL: Effect of Vitamin D and Calcium Supplementation on Cancer Incidence in Older Women: A Randomized Clinical Trial. JAMA 317: 1234-1243, 2017.

44 Scragg R, Stewart AW, Waayer D, Lawes CMM, Toop L, Sluyter J, Murphy J, Khaw KT and Camargo CA Jr.: Effect of monthly high-dose vitamin D supplementation on cardiovascular disease in the Vitamin D Assessment Study: a randomized clinical trial. JAMA Cardiol 2: 608-616, 2017.

45 Zittermann A, Ernst JB, Prokop S, Fuchs U, Dreier J, Kuhn J, Knabbe C, Birschmann I, Schulz U, Berthold HK, Pilz S, GouniBerthold I, Gummert JF, Dittrich M and Börgermann J: Effect of vitamin D on all-cause mortality in heart failure (EVITA): a 3 -year randomized clinical trial with 4000 IU vitamin D daily. Eur Heart 38: 2279-2286, 2017.

46 Pilz S, Gaksch M, Kienreich K, Grübler M, Verheyen N, Fahrleitner-Pammer A, Treiber G, Drechsler C, Ó Hartaigh B, Obermayer-Pietsch B, Schwetz V, Aberer F, Mader J, Scharnagl H, Meinitzer A, Lerchbaum E, Dekker JM, Zittermann A, März $\mathrm{W}$ and Tomaschitz A: Effects of vitamin D on blood pressure and cardiovascular risk factors: a randomized controlled trial. Hypertension 65: 1195-1201, 2015.

47 Gaksch M, Jorde R, Grimnes G, Joakimsen R, Schirmer H, Wilsgaard T, Mathiesen EB, Njølstad I, Løchen ML, März W, Kleber ME, Tomaschitz A, Grübler M, Eiriksdottir G, Gudmundsson EF, Harris TB, Cotch MF, Aspelund T, Gudnason V, Rutters F, Beulens JW, van 't Riet E, Nijpels G, Dekker JM, Grove-Laugesen D, Rejnmark L, Busch MA, Mensink GB, Scheidt-Nave C, Thamm M, Swart KM, Brouwer IA, Lips P, van Schoor NM, Sempos CT, Durazo-Arvizu RA, Škrabáková Z, Dowling KG, Cashman KD, Kiely M and Pilz S: Vitamin D and mortality: Individual participant data meta-analysis of standardized 25-hydroxyvitamin D in 26916 individuals from a European consortium. PLoS One 12: e0170791, 2017.

48 Grant WB and Boucher BJ: Randomized controlled trials of vitamin D and cancer incidence: A modeling study. PLoS One 12: e0176448, 2017. 
49 Scragg R: Limitations of vitamin D supplementation trials: Why observational studies will continue to help determine the role of vitamin D in health. J Steroid Biochem Mol Biol, 2017. doi: 10.1016/j.jsbmb.2017.06.006 [Epub ahead of print]

50 Bischoff-Ferrari HA, Dawson-Hughes B, Orav EJ, Staehelin HB, Meyer OW, Theiler R, Dick W, Willett WC and Egli A: Monthly high-dose vitamin $\mathrm{D}$ treatment for the prevention of functional decline: a randomized clinical trial. JAMA Intern Med 176: 175$183,2016$.

51 Verduijn M, Siegerink B, Jager KJ, Zoccali C and Dekker FW: Mendelian randomization: use of genetics to enable causal inference in observational studies. Nephrol Dial Transplant 25: 1394-1398, 2010

52 Vimaleswaran KS, Cavadino A, Berry DJ; LifeLines Cohort Study investigators, Jorde R, Dieffenbach AK, Lu C, Alves AC, Heerspink HJ, Tikkanen E, Eriksson J, Wong A, Mangino M, Jablonski KA, Nolte IM, Houston DK, Ahluwalia TS, van der Most PJ, Pasko D, Zgaga L, Thiering E, Vitart V, Fraser RM, Huffman JE, de Boer RA, Schöttker B, Saum KU, McCarthy MI, Dupuis J, Herzig KH, Sebert S, Pouta A, Laitinen J, Kleber ME, Navis G, Lorentzon M, Jameson K, Arden N, Cooper JA, Acharya J, Hardy R, Raitakari O, Ripatti S, Billings LK, Lahti J, Osmond C, Penninx BW, Rejnmark L, Lohman KK, Paternoster L, Stolk RP, Hernandez DG, Byberg L, Hagström E, Melhus H, Ingelsson E, Mellström D, Ljunggren O, Tzoulaki I, McLachlan S, Theodoratou E, Tiesler CM, Jula A, Navarro P, Wright AF, Polasek O; International Consortium for Blood Pressure (ICBP); Cohorts for Heart and Aging Research in Genomic Epidemiology (CHARGE) consortium; Global Blood Pressure Genetics (Global BPGen) consortium; Caroline Hayward, Wilson JF, Rudan I, Salomaa V, Heinrich J, Campbell H, Price JF, Karlsson M, Lind L, Michaëlsson K, Bandinelli S, Frayling TM, Hartman CA, Sørensen TI, Kritchevsky SB, Langdahl BL, Eriksson JG, Florez JC, Spector TD, Lehtimäki T, Kuh D, Humphries SE, Cooper C, Ohlsson C, März W, de Borst MH, Kumari M, Kivimaki M, Wang TJ, Power C, Brenner H, Grimnes G, van der Harst P, Snieder H, Hingorani AD, Pilz S, Whittaker JC, Järvelin MR and Hyppönen E: Association of vitamin D status with arterial blood pressure and hypertension risk: a Mendelian randomisation study. Lancet Diabetes Endocrinol 2: 719-729, 2014.
53 Zittermann A, Pilz S, Hoffmann H and März W: Vitamin D and airway infections: a European perspective. Eur J Med Res 21: 14,2016

54 Martineau AR, Jolliffe DA, Hooper RL, Greenberg L, Aloia JF, Bergman P, Dubnov-Raz G, Esposito S, Ganmaa D, Ginde AA, Goodall EC, Grant CC, Griffiths CJ, Janssens W, Laaksi I, Manaseki-Holland S, Mauger D, Murdoch DR, Neale R, Rees JR, Simpson S Jr., Stelmach I, Kumar GT, Urashima M and Camargo CA Jr. Vitamin D supplementation to prevent acute respiratory tract infections: systematic review and meta-analysis of individual participant data. BMJ 356: i6583, 2017.

55 Manousaki D, Mokry LE, Ross S, Goltzman D and Richards JB: Mendelian randomization studies do not support a role for vitamin D in coronary artery disease. Circ Cardiovasc Genet 9: 349-356, 2016.

56 Pilz S, Grübler M, Gaksch M, Schwetz V, Trummer C, Hartaigh BÓ, Verheyen N, Tomaschitz A and März W: Vitamin D and Mortality. Anticancer Res 36: 1379-1387, 2016.

57 Rhead B, Bäärnhielm M, Gianfrancesco M, Mok A, Shao X, Quach H, Shen L, Schaefer C, Link J, Gyllenberg A, Hedström AK, Olsson T, Hillert J, Kockum I, Glymour MM, Alfredsson L and Barcellos LF: Mendelian randomization shows a causal effect of low vitamin D on multiple sclerosis risk. Neurol Genet 2: e97, 2016.

58 Mokry LE, Ross S, Morris JA, Manousaki D, Forgetta V and Richards JB: Genetically decreased vitamin D and risk of Alzheimer disease. Neurology 87: 2567-2574, 2016.
Received October 30, 2017

Revised December 5, 2017

Accepted December 6, 2017 